DOI: 10.46340/ephd.2020.6.1.12

\title{
Інна Білоцерківська
}

Переяслав-Хмельницький державний педагогічний університет

імені Григорія Сковороди, Україна

\section{РОЗБУДОВА ТА ФУНКЦІОНУВАННЯ МЕРЕЖІ ШКІЛ-ІНТЕРНАТІВ СУМСЬКОЇ ОБЛАСТІ \\ У 1950-2020 pp.}

\author{
Inna Bilotserkivska \\ ORCID ID: https://orcid.org/0000-0002-4923-1083 \\ Pereiaslav-Khmelnytskyi Hryhorii Skovoroda State Pedagogical University, Ukraine \\ DEVELOPMENT AND FUNCTIONING \\ OF THE BOARDING SCHOOLS NETWORK \\ IN THE SUMY REGION IN 1950-2020
}

\begin{abstract}
The purpose of the study is to explore the ways the boarding schools' network in the Sumy region was established and functioned over the period from 1950-2020. An overall conclusion is that the network of boarding schools in the Sumy region started to actively grow and develop in the 1950s - 1960s after the initiative by M.S. Khrushchev. $73 \%$ of the boarding schools in the region were built over the period from 1957 to 1968. Construction of the boarding infrastructure in the region progressed rather fast. According to the seven-year-plans, 1-2 boarding schools were to be raised in each district at the expense of local collective farms, although these establishments had never become widespread as the new types of educational institutions required considerable logistical support. After Ukraine gained independence in 1991, specialised boarding schools in the Sumy region were established in various fields of study but mainly for gifted children. Starting from 2018, many institutions were reorganized and some of them were closed in line with the new Law «On Education».

Keywords: boarding school, school education of Sumy region, Law «On Education», XX Congress of the Communist Party of the USSR.
\end{abstract}

Школа-інтернат - це заклад з цілодобовим перебуванням дітей, створений з метою їх проживання, розвитку, виховання, освіти, професійної орієнтації, підготовки до самостійного життя. Відповідно до нового Закону «Про освіту» (2017р.) школи-інтернати повинні бути перетворені у дитячі будинки і перейти у підпорядкування центрального органу виконавчої влади усфері соціального захисту. Щоб оцінити доцільність цього рішення, варто дослідити процеси створення та функціонування мережі цих закладів в Україні загалом та у Сумській області зокрема.

Обставини виникнення в системі народної освіти України другої половини 1950-х рр. загальноосвітніх шкіл-інтернатів висвітлено у працях Н.Б. Антонець ${ }^{12}$, у звіті Інституту педагогіки про науково-дослідну роботу з теми «Організація навчального процесу в історії вітчизняної школи: від уніфікації до диференціації (40-80-ті рр. ХX ст.)»³ та ін.

\footnotetext{
${ }^{1}$ Антонець, Н. Б. (2015). В. Сухомлинський у полеміці щодо створення шкіл-інтернатів. Педагогічний альманах, 26, 258-265.<http://nbuv.gov.ua/UJRN/pedalm_2015_26_44> (2020, січень, 26).

2 Антонець, Н. Б. (2015). Загальноосвітня школа-інтернат як складова системи народної освіти України (друга половина 1950-х рр.). Інноватика у вихованні. 2015. Вип. 2.111-126.

URL: http://nbuv.gov.ua/UJRN/inuv_2015_2_14> (2020, березень, 20).

${ }^{3}$ Дічек, Н. П., Сухомлинська, О. В., Пироженко, Л. В. та інші (2016). Звіт про науково-дослідну роботу з теми - Організація навчального процесу в історії вітчизняної иколи: від уніфікації до диференціації (40-80-mi pp. XX cm.) МОН України, Нац. акад. пед. наук України, Ін-т педагогіки, 75.

URL: http://undip.org.ua/files/docs/Zakl_zvit_2013_2015_ist_pedegogiky.pdf> (2020, лютий, 13).
} 
Метою дослідження є виявлення особливостей розбудови та функціонування мережі шкілінтернатів Сумської області у 1950-2020 pp.

У 1956 р. в УРСР виник новий тип освітнього закладу - школа-інтернат. Під час ХХ з'їзду Комуністичної партії СРСР (14-25 лютого 1956 р., м. Москва) Перший секретар ЦК КПРС М.С. Хрущов, висвітлюючи питання освіти, озвучив нову ініціативу партії, що вносила суттєві зміни у шкільництво всіх союзних республік. Новий тип навчально-виховного закладу був покликаний на більш високому рівні виконувати завдання підготовки всебічно розвинених, освічених будівників комунізму i таким чином сприяти докорінному покращенню роботи з виховання та освіти підростаючого покоління ${ }^{1}$ У п постанові ЦК КПУ і Ради Міністрів УРСР від 20 жовтня 1956 р. «Про заходи по подальшому розвитку мережі шкіл-інтернатів Українській РСР» регламентувалася кількість вихованців шкіл-інтернатів, визначався порядок прийому до навчальних закладів, акцентувалась увага, що, перш за все, до шкіл-інтернатів приймали дітей одиноких матерів, інвалідів війни та праці, сиріт та дітей, для виховання яких відсутні необхідні умови в сім'ї. За утримання дітей батьки сплачували частку щомісячної зарплати. На повне державне забезпечення приймалися діти, які не мали батьків².

У 1950-х рр. в УРСР, як і в усьому Радянському Союзі, інтернати функціонували при школах, де навчалися діти з фізичними вадами (за термінологією того часу). У 1956 р. Міністерство освіти УРСР затвердило «Положення про школи для глухонімих дітей», «Положення про школи для сліпих дітей» та «Положення про допоміжні школи для розумово відсталих дітей», що мали окремий типовий розділ, присвячений інтернатам. У ньому зазначалося, що ті учні цих шкіл, які не мають батьків, а також учні, батьки яких проживають в іншій місцевості, приймаються до інтернатів, де вся робота з вихованцями має бути підпорядкована загальним завданням конкретної спеціальної школиз

У грудні 1958 р. було прийнято Закон «Про зміцнення зв’язку школи з життям і про дальший розвиток народної освіти в СРСР» ${ }^{4}$, у квітні 1959 р. Верховна Рада Української РСР відповідно до Закону СРСР ухвалила Закон «Про зміцнення зв'язку школи з життям і про дальший розвиток системи народної освіти в УРСР» ${ }^{5}$, де однією 3 проблем зазначалося розширення мережі шкілінтернатів. Таким чином, з другої половини 1950-х рр. ХХ ст. в Сумській області, як і на всій території УРСР, розпочалося активне будівництво шкіл-інтернатів.

Згідно звітних матеріалів станом на 1959 р. в Сумській області налічувалося 2 школиінтернати - Миропільська і Охтирська 3 контингентом біля 500 учнів. На виконання постанови Ради Міністрів СРСР від 31 січня 1959 р. № 131 «Про заходи з розширення мережі шкіл-інтернатів в Українській РСР у 1959 р.» та Постанови ЦК КПРС і Ради Міністрів СРСР від 19 травня 1959 р. № 533 «Про заходи з розвитку шкіл-інтернатів в 1959-1965 роках» в області планувалося вже в 1959 р. відкрити 5 шкіл-інтернатів на 210 чоловік кожна ${ }^{6}$.

- Білопільська - спочатку функціонувала як міжшкільний інтернат при Білопільській середній школі № 2 на 30 учнівських місць для учнів із села, які продовжували навчання в старших класах шкіл м. Білопілля. У 2018 р. реорганізовано в Білопільський заклад загальної середньої освіти I-III ступенів № 5 ім. А.С. Макаренка Білопільської районної ради Сумської області.

${ }^{1}$ Дічек, Н. П., Сухомлинська, О. В., Пироженко, Л. В.та інші (2015). Звіт про науково-дослідну роботу з теми Організачія навчального прочесу в історї̈ вітчизняної школи: від уніфікації до диференціації (40-80-ті рр. XX cm.). МОН України, Нац. акад. пед. наук України, Ін-т педагогіки.

$<$ http://undip.org.ua/files/docs/Zakl_zvit_2013_2015_ist_pedegogiky.pdf> (2020, лютий, 13).

2 Збірник наказів та розпоряджень Міністерства освіти УРСР (1956). Про виконання постанови ЦК КПУ, Ради Міністрів УРСР від 20 жовтня 1956 р. Про заходи по подальшому розвитку шкіл-інтернатів в Українській РСР, 24. 3.

3 Дічек, Н. П., Сухомлинська, О. В., Пироженко, Л. В.та інші (2015). Звіт про науково-дослідну роботу з теми Організація навчального процесу в історії вітчизняної школи: від уніфікації до диферениіаиї (40-80-ті рр. XX cm.). МОН України, Нац. акад. пед. наук України, Ін-т педагогіки.

$<$ http://undip.org.ua/files/docs/Zakl_zvit_2013_2015_ist_pedegogiky.pdf> (2020, лютий, 13).

4 Закон об укреплении связи школьы с жизнью и о дальнейшем развитии системы народного образования в СССР, 1958. (Верховный Совет СССР) Москва.

5 Закон про зміцнення зв 'язку школи з життям і про дальший розвиток системи народної освіти в Украӥнській РСР, 1959 (Верховна Рада УРСР). Київ: Радянска школа.

6 Звіт Сумського облвно про роботу шкіл і відділів народної освіти в 1958/1959 н.р. Державний архів Сумської області (ДАСО). Ф. Р-3552. Оп. 1. Спр. 266. Арк. 67-70. 
- Правдинська - організована улипні 1959 р. на базі дитячого будинку. Нині заклад функціонує як Комунальний заклад Сумської обласної ради (КЗ СОР) Правдинська спеціальна загальноосвітня школа-інтернат I-II ступенів Великописарівського району.

- Роменська - створена на базі колишньої міської школи № 4 та дитячого будинку № 1 . 1 вересня 2015 р. школу-інтернат реорганізовано в Роменське відділення КЗ СОР «Сумська обласна гімназія-інтернат для талановитих та творчо обдарованих дітей».

- Грунська - до 2018 р. функціонувала як КЗ СОР Грунська спеціальна загальноосвітня школаінтернат Охтирського району.

- Путивльська - створена на базі колишнього дитячого будинку, навчальний корпус побудовано у 1963 р. Нині КЗ СОР Путивльська спеціалізована мистецька школа-інтернат $€$ спеціалізованим навчальним закладом I-III ступенів.

Крім того, у звітних матеріалах зазначається, що керівними органами планувалося впродовж 7 років побудувати $1-2$ школи-інтернати в кожному районі за рахунок колгоспів ${ }^{1}$.

3'ясовано, що станом на 1961 р. функціонувало 8 шкіл-інтернатів, де навчалося 2070 учнів. Переважна більшість вихованців були діти-сироти і напівсироти; із 2070 учнів - 318 сиріт, 1145 напівсиріт, 607 чоловік, які мали батьків. За соціальним станом було: дітей робітників - 619, службовців - 462, колгоспників - 694, інших - 295 осіб. У тому числі з дитячих будинків біля 400 учнів. Всі школи мали швейні майстерні, майстерні по металу й дереву, майстерні з ремонту взуття. На час літніх канікул усі діти перебували в оздоровчих таборах. Якісний склад педагогічних кадрів шкіл-інтернатів був кращий, ніж в деяких середніх школах. Директори шкіл, завучі, старші вихователі мали вищу освіту. Всього педагогічних працівників було 236, із них 117 вчителів і 119 вихователів. Вищу освіту мали 155 , незакінчену вищу -21 , середню педагогічну -49 , не мали педагогічної освіти $-11^{2}$.

Встановлено, що, як і в інших школах, в зазначених закладах велика увага приділялася самообслуговуванню, роботі в шкільних майстернях, навчально-дослідних господарствах. 4 школи мали власні трактори, майже всі роботи з догляду за посівами і збирання врожаїв виконували учні. За профілем швейної та столярної справи здійснювалося виробниче навчання у Миропільській (на власній базі) та Охтирській (на базі місцевої швейної фабрики та заводу медичних меблів) школахінтернатах. У школах, де було виробниче навчання, зініціювалося введення в штат завідувача навчально-виробничими майстернями ${ }^{3}$.

Незважаючи на те, що школам-інтернатам приділялася особлива увага керівних органів області, слабкою ланкою в організації інтернатних установ стало їх матеріально-технічне забезпечення. Школи-інтернати формувалися за типом восьмирічної або середньої загальноосвітньої політехнічної школи з виробничим навчанням. Організація навчально-технічної бази шкіл-інтернатів мала відповідати певним технічним характеристикам: наявність необхідної кількості класних кімнат, навчальних кабінетів, навчально-виробничих майстерень, спортивної зали, бібліотеки з читальним залом, кімнат для відпочинку ${ }^{4}$. Кожен навчально-виховний заклад повинен був мати спальні кімнати для вихованців, харчоблок із їдальнею, ізолятор, учительську, піонерську кімнату, приміщення для побачення з батьками тощо. Окрім цього, викладачі й вихователі шкіл-інтернатів мали бути забезпечені житлом, тому навчальний заклад повинен був мати житловий будинок для педагогічного персоналу ${ }^{5}$.

Доведено також, що форсовані темпи розбудови шкіл-інтернатів Сумської області, позірна боротьба за показники й звітність призводили до появи випадків уведення державними комісіями в експлуатацію новобудов зі значними недоробками. Про це свідчать спогади першого директора Шосткінської загальноосвітньої школи-інтернату I-III ступенів, відмінника освіти УРСР

\footnotetext{
1 Звіт Сумського облвно про роботу шкіл і відділів народної освіти в 1958/1959 н.р. ДАСО. Ф. P-3552. On. 1. Спр. 266. Арк. 87.

2 Річний звіт про роботу шкіл Сумської області за 1960-1961 н/p. Центральний державний архів вищих органів влади та управління України (ЦДАВО України). Ф. 166. On. 15. Сnp. 3212. Арк. 258-259.

${ }^{3}$ Річний звіт про роботу шкіл Сумської області за 1960-1961 н/р. ЦДАВО України. Ф. 166. On. 15. Cnp. 3212. Арк. 266-270.

4 Червоний прапор (1959)..Школа нового типу. 1 квітня, 2.

5 Збірник наказів та розпоряджень Міністерства освіти УРСР (1957). Про затвердження Положення про школи-інтернати Міністерства освіти УРСР, 12-13, 7.
} 
П.І. Костерева (1962-1977): «Ми починали роботу з нуля, коли не було необхідних умов для життя вихованців та навчально-матеріальної бази. В ̈̈дальні перший час не було жодної вилки, не вистачало каструль для приготування їжі, в окремих кімнатах гуртожитку i класах навчального корпусу температура була значно нижчою за встановлені норми. Все це результат поспішного відкриття школи-інтернату... А в перші 10 днів на першому поверсі навчального корпусу обвалилася підлога: будівельники забули з'єднати між собою окремі ділянки каналізаційних труб...»${ }^{1}$.

Разом з тим слід відмітити, що переважна більшість інтернатних закладів Сумської області організована в радянський період. До 1968 р., крім названих, створено такі школи-інтернати (деякі заклади не вказані серед звітних матеріалів за 1959 р., оскільки на той час населені пункти не входили до складу Сумської області):

- КЗ СОР Лебединська спеціальна загальноосвітня школа-інтернат - має 60-літній досвід у навчанні, вихованні, реабілітації глухих дітей, їх адаптації в суспільство.

- КЗ СОР Штепівська спеціальна загальноосвітня школа-інтернат Лебединського району організована у 1957 р. згідно рішення виконкому обласної ради, на базі Лебединського дитячого будинку № 3. У 2018 р. заклад змінив назву на Штепівський навчально-реабілітаційний центр Лебединського району.

- КЗ СОР Шалигинська загальноосвітня спеціальна школа-інтернат Глухівського району заснована 1959 р. на базі Олевської допоміжної школи-інтернату Охтирського району. На сьогодні це спеціальна загальноосвітня школа-інтернат для дітей з вадами у фізичному та розумовому розвитку.

- КЗ СОР Улянівська спеціальна загальноосвітня школа-інтернат Білопільського району відбудована у 1960 р. як Улянівська трудова політехнічна школа-інтернат. У 1975 р. загальноосвітній інтернат було розформовано, дітей перевели до закладу в м. Білопілля. А в приміщення переселили допоміжну школу-інтернат 3 м. Ворожби, разом 3 частиною медпрацівників. 32010 р. школа функціонує як навчальний заклад для дітей, які потребують корекції фізичного та розумового розвитку.

- КЗ СОР Шосткінська загальноосвітня школа-інтернат I-III ступенів - створена у 1962 р. У 2018 р. на сесії Сумської обласної ради було прийнято рішення про ліквідацію КЗ «Шосткинська загальноосвітня школа-інтернат», та створення нового навчального закладу - «Шосткинський ліцейінтернат спортивного профілю».

- Конотопська спеціальна загальноосвітня школа-інтернат- побудована у 1962 р. як Конотопська школа-інтернат № 2, 1 вересня 1979 р. перепрофільована на спеціальну школу-інтернат для слабозорих дітей.

- КЗ СОР Конотопська загальноосвітня санаторна школа-інтернат I-II ступенівзаснована улистопаді 1963 р. як навчально-реабілітаційний заклад для дітей з малими та затухаючими формами туберкульозу.

- Глухівський лічей-інтернат з посиленою військово-фізичною підготовкою - побудований у 1965 р. Згідно $з$ постановою Ради Міністрів України від 14 червня 1982 р. № 325 восьмирічній школі-інтернату було присвоєно ім'я Героя Радянського Союзу Миколи Івановича Жужоми. Упродовж 2013-20118 pр. він мав назву «Глухівська загальноосвітня школа-інтернат I-III ступенів ім. М.І. Жужоми», а з 2018 р. - КЗ СОР Глухівський ліцей-інтернат з посиленою військово-фізичною підготовкою.

- КЗ СОР Глинська спеціальна загальноосвітня школа-інтернат - сформована у 1968 p. на місці дитячого будинку для дітей, які мають проблеми у навчанні.

До 1963/1964 навчального року значно зросла кількість інтернатів при школах. Наприклад, в Охтирському районі їх налічувалося 21 (без шкіл-інтернатів), де проживало 680 учнів 2 .

3'ясовано, що наприкінці 1970-х рр. в Україні затвердився такий перелік типів інтернатних закладів: а) загальноосвітні школи-інтернати загального типу для дітей, які не мали необхідних умов для виховання у сім’ї; б) дитячі будинки та загальноосвітні школи-інтернати для дітей-сиріт і дітей, що залишилися без піклування батьків; в) загальноосвітні оздоровчі санаторно-лісні школи, санаторні

\footnotetext{
${ }^{1}$ Костерев, П. И. (2020). Первые страницы истории Шосткинской общеобразовательной школы - интерната 1962-1977 годы. Сайт Комунального закладу Сумської обласної ради Шосткинський ліщей-інтернат спортивного профілю $<$ http://zoshi.ucoz.ua/index/istorija_zakladu/0-19> (2020, березень, 20).

${ }^{2}$ Пояснююча записка до статистичного звіту форми РВК № 75 та А-ІІІ в по Охтирському району за 1963-1964 н/p. ДАСО. ф. p-3552, on. 3, спр. 16, арк. 12.
} 
школи-інтернати для дітей з різними захворюваннями, санаторні дитячі будинки; г) спеціальні загальноосвітні школи-інтернати та дитячі будинки для дітей, що мали недоліки у фізичному або розумовому розвитку, що перешкоджають їхньому навчанню у звичайній загальноосвітній школі; д) спеціалізовані загальноосвітні школи-інтернати для поглибленої підготовки дітей у галузі науки, мистецтва та спорту; е) інтернати при загальноосвітніх школах та при середніх спеціальних музичних та художніх школах ${ }^{1}$.

Встановлено, що у період 1968-1979 рр. активне будівництво шкіл-інтернатів в Сумській області взагалі припинилося. За 1979-1989 рр. організовано такі інтернатні заклади:

- КЗ СОР Сумський дитячий будинок ім. С.П. Супруна - відкрито у 1979 р. як школу-інтернат.

- КЗ СОР Косівщинська спеціальна загальноосвітня школа-інтернат Сумського районувідкрито у 1989 р. як загальноосвітній навчальний заклад для дітей, які потребують корекції порушень слуху.

Після здобуття Україною незалежності відбулися процеси перебудови народного господарства, що супроводжувалися складним фінансовим становищем освітніх (та інших) закладів. У 1994-1999 pр. низька заробітна плата освітян супроводжувалася іiі затримками на 2-6 місяців. За спогадами директора Шосткінської загальноосвітньої школи-інтернату I-III ступенів М.Г. Шевченка (1992-2000), зі шкіл-інтернатів почали звільнятися кваліфіковані спеціалісти, які вміли і могли працювати з дітьми. Не виділялися гроші навіть на найнеобхідніше: бензин, медикаменти, санітарно-гігієнічні та миючі засоби. Крім того, спад виробництва на підприємствах області привів до відміни шефських зв'язків і різкого скорочення допомоги загальноосвітнім закладам регіону. Різко впав інтерес до навчання в учнів, тому що вступати після закінчення школи у вузи і технікуми було дуже складно у зв'язку з їх переходом на комерційну основу, а профтехучилища не забезпечували зайнятості випускників. Значно зросли в цей період правопорушення серед учнів, причому деякі з них під керівництвом батьків. Колективи шкілінтернатів докладали максимум зусиль, щоб зберегти матеріально-технічну базу закладів, поліпшити навчально-виховну роботу, створити умови для своїх вихованців ${ }^{2}$.

Незважаючи на такі складні умови, інтернатні заклади продовжили свою роботу, більшість із них була реорганізована. Разом з тим за час існування незалежності держави в Сумській області створено нові заклади інтернатного типу:

- Комунальна установа Сумська спеціальна загальноосвітня школа-інтернат для дітей, які потребують корекції розумового та фізичного розвитку - створена рішенням виконавчого комітету Сумської міської Ради № 245 від 23 липня 1992 р.

- КЗ СОР Сумська обласна гімназія-інтернат для талановитих та творчо обдарованих дітей - утворена рішенням сесії обласної ради від 29 листопада 2005 р.

- КЗ СОР Обласний лічей-інтернат спортивного профілю «Барса» (м. Суми) - створено відповідно до програми розвитку футболу в Сумській області, затвердженої у 2012 р. Сумською обласною державною адміністрацією з метою досягнення високих спортивних результатів та підготовки спортсменів до національних збірних команд України з видів спорту футбол та біатлон.

- Державний лічей-інтернат з посиленою військово-фізичною підготовкою «Кадетський корпус» імені І.Г. Харитоненка Державної прикордонної служби Украӥни (м. Суми) - створений 21 вересня 2007 р. рішенням Сумської обласної ради з метою якісної підготовки кандидатів для вступу до вищих навчальних закладів і закладів інших міністерств (силових структур), надання державної допомоги у вихованні дітей-сиріт і дітей з багатодітних сімей. У 2019 р. заклад переданий до сфери управління Адміністрації Державної прикордонної служби України.

Крім того, як вже зазначалося, у 2018 р. деякі інтернатні заклади області ліквідовано або реорганізовано. Це пов'язано з тим, що згідно з Законом «Про освіту», прийнятого у 2017 р.

\footnotetext{
${ }^{1}$ Дічек, Н. П., Сухомлинська О. В., Пироженко Л. В. та інші (2016). Звіт про науково-дослідну роботу 3 теми Організація навчального процесу в історії вітчизняної школи: від уніфікації до диференціації (40-80-ті pp. XX ст.), 41-42. Інститут педагогіки НАПН Украӥни > http://undip.org.ua/files/docs/Zakl_zvit_2013_2015_ist_pedegogiky.pdf> (2020, лютий, 13).

${ }^{2}$ Шевченко Н. Г. (2020). Странички летописи школы - интерната. Сайт Комунального закладу Сумської обласної ради Шосткинський ліцей-інтернат спортивного профілю $<$ http://zoshi.ucoz.ua/index/istorija_zakladu/0-19> (2020, березень, 20).
} 
(05.09.2017 № 2145-VIII), до 1 вересня 2018 р. органам місцевого самоврядування потрібно було забезпечити зміну типу підпорядкованих шкіл-інтернатів (крім закладів середньої освіти для дітей 3 порушенням інтелектуального розвитку) на гімназію, ліцей відповідно до вимог цього Закону із збереженням у складі цих закладів освіти інтернатів з частковим або повним утриманням учнів (вихованців) за рахунок засновника (засновників) ${ }^{1}$. Згідно з Законом «Про освіту» існуючі школиінтернати для дітей-сиріт та дітей, позбавлених батьківського піклування, школи-інтернати для дітей, які потребують соціальної допомоги, перетворюються до 31 грудня 2021 р. у дитячі будинки та переходять у підпорядкування центрального органу виконавчої влади усфері соціального захисту або в заклади дошкільної, середньої освіти, інші заклади освіти чи соціального захисту за рішенням обласних рад, Верховної Ради Автономної Республіки Крим, міських рад міст Києва та Севастополя.

Таким чином, можна стверджувати, що після здобуття Україною незалежності в Сумській області організовано школи-інтернати переважно для обдарованих дітей за різними напрямами, а з 2018 р. відбулася реорганізація багатьох закладів та ліквідація деяких із них відповідно до нового Закону «Про освіту».

Отже, на основі вищесказаного можна зробити висновок, що мережа шкіл-інтернатів Сумщини активно почала формуватися у 1950-1960-х рр. після ініціативи М.С. Хрущова. Розбудова інтернатних установ проходила в області досить інтенсивно, планувалося впродовж 7 років побудувати 1-2 школи-інтернати в кожному районі за рахунок фінансової допомоги від колгоспів, проте ці заклади так і не стали масовими. Нові типи навчальних закладів потребували значного матеріально-технічного забезпечення. 73\% шкіл-інтернатів області було побудовано у період $1957-$ 1968 pр. Створені після 1991 р. інтернатні заклади (18 \% від загальної кількості інтернатів регіону) покликані розвивати творчі та фізичні здібності дітей. Після прийняття Закону «Про освіту» у 2017 р. відбувається реорганізація інтернатних закладів, що продовжиться до 2021 р.

\section{References:}

1. Antonets, N. B. (2015). V. Sukhomlynskyi u polemitsi shchodo stvorennia shkil-internativ [Sukhomlinsky in the controversy on the establishment of boarding schools]. Pedahohichnyi almanakh [Pedagogical almanac], 26, 258-265. <http://nbuv.gov.ua/UJRN/pedalm_2015_26_44> (2020, January, 26). [in Ukrainian].

2. Antonets, N. B. (2015). Zahalnoosvitnia shkola-internat yak skladova systemy narodnoi osvity Ukrainy (druha polovyna 1950-kh rr.) [General boarding school as a component of the system of public education in Ukraine (second half of 1950s)]. Innovatyka u vykhovanni [Innovation in education], 2, 111-126. $<$ http://nbuv.gov.ua/UJRN/inuv_2015_2_14> (2020, March, 03). [in Ukrainian].

3. Dichek, N. P., Sukhomlynska, O. V., Pyrozhenko and others (2015). Zvit pro naukovo-doslidnu robotu z temy Orhanizatsiia navchalnoho protsesu $\mathrm{v}$ istorii vitchyznianoi shkoly: vid unifikatsii do dyferentsiatsii (40-80-ti rr. $\mathrm{XX}$ st.). [Report on research work on the topic - Organization of the educational process in the history of the national school : from unification to differentiation (40-80-ies of the 20th century)]. Instytut pedahohiky NAPN Ukrayiny [Institute of Pedagogy of the National Academy of Pedagogical Sciences of Ukraine] $<$ http://undip.org.ua/files/docs/Zakl_zvit_2013_2015_ist_pedegogiky.pdf $>$ (2020, February, 13). [in Ukrainian].

4. Pro vykonannia postanovy TsK KPU, Rady Ministriv URSR vid 20 zhovtnia 1956 r. «Pro zakhody po podalshomu rozvytku shkil-internativ v Ukrainskii RSR, 1956 [On the implementation of the resolution of the Central Committee of the Communist Party of Ukraine, the Council of Ministers of the USSR of October 20, 1956 On measures for the further development of boarding schools in the Ukrainian SSR, 1956]. Zbirnyk nakaziv ta rozporiadzhen Ministerstva osvity URSR [Collection of orders and orders of the Ministry of Education of the USSR], 24, 3. [in Ukrainian].

5. Zakon ob ukreplenii svjazi shkoly s zhiznju i o dalnejshem razvitii sistemy narodnogo obrazovanija v SSSR,1958 [The law on strengthening the connection of schools with life and on the further development of the public education system in the USSR, 1958]. Moscow. [in Russian].

6. Zakon pro zmitsnennia zviazku shkoly z zhyttiam i pro dalshyi rozvytok systemy narodnoi osvity v Ukrainskii RSR, 1959 [The Law on Strengthening the Relationship of the School with Life and Further Development of the Public Education System in the Ukrainian SSR, 1959]. Kyiv. [in Ukrainian].

7. Zvit Sumskoho oblvno pro robotu shkil i viddiliv narodnoi osvity v 1958/1959 n. r., 1959 [Sumy Regional Report on the Work of Schools and Public Education Departments in 1958/1959, 1959]. Derzhavnyi arkhiv Sumskoi oblasti [State Archives of Sumy Region], f. R-3552, op. 1, spr. 266. [in Ukrainian].

1 Закон про освіту, 2017 (Верховна Рада України). Законодавство України

$<$ https://zakon.rada.gov.ua/laws/main/index> (2020, березень, 20). 
8. Richnyi zvit pro robotu shkil Sumskoi oblasti za 1960-1961 n/r [Annual report on the work of schools of Sumy region for 1960-1961 academic year]. Tsentralnyi derzhavnyi arkhiv vyshchykh orhaniv vlady ta upravlinnia Ukrainy [Central State Archives of Higher Authorities and Administration of Ukraine], f. 166, op. 15, spr. 3212.

9. Shkola novoho typu (1959). [A new type of school (1959)]. Chervonyi prapor [Red flag], 1, 2. [in Ukrainian].

10. Pro zatverdzhennia polozhennia pro shkoly-internaty Ministerstva osvity URSR (1957). [On approval of the «Regulations on boarding schools of the Ministry of Education of the USSR (1957)]. Zbirnyk nakaziv ta rozporiadzhen Ministerstva osvity URSR [Collection of orders and orders of the Ministry of Education of the USSR], 12-13, 7. [in Ukrainian].

11. Kosterev, P. I. (2020). Pervye stranicy istorii Shostkinskoj obshheobrazovatelnoj shkoly - internata 1962-1977 gody [The first pages of the history of the Shostka comprehensive school - boarding school 1962-1977]. Sait Komunalnoho zakladu Sumskoi oblasnoi rady Shostkynskyi litsei-internat sportyvnoho profiliu [Website of the Municipal Institution of Sumy Regional Council Shostka Lyceum-boarding school of sports profile]. $<$ http://zoshi.ucoz.ua/index/istorija_zakladu/0-19> (2020, March, 20). [in Russian].

12. DASO [SASR] (1964). Poiasniuiucha zapyska do statystychnoho zvitu formy RVK № 75 ta A-III v po Okhtyrskomu raionu za 1963-1964 n/r. [Explanatory note to the statistical report on the form of RECs no. 75 and A-III in the Okhtyrsky District for 1963-1964 academic year]. f. R-3552, op. 3, spr. 16. [in Ukrainian].

13. Shevchenko, N. G. (2020). Stranichki letopisi shkoly-internata [The pages of the chronicle of the boarding school]. Sait Komunalnoho zakladu Sumskoi oblasnoi rady Shostkynskyi litsei-internat sportyvnoho profiliu [Website of the Municipal Institution of the Sumy Regional Council Shostka lyceum-boarding school sports profile]. $<$ http://zoshi.ucoz.ua/index/istorija_zakladu/0-19> (2020, March, 20). [in Russian].

14. Zakon pro osvitu, 2017 (Verkhovna Rada Ukrayiny) [Law on Education, 2017 (Verkhovna Rada of Ukraine)]. Zakonodavstvo Ukrayiny [The legislation of Ukraine]. <https://zakon.rada.gov.ua/laws/main/index> (2020, March, 20). [in Ukrainian]. 